\title{
25 Research Square \\ Predictor Analysis of Middle and Low Achieving Students in Cell Biology Online Course in Health Nutrition Undergraduate Program
} \section{Universitas Gadjah Mada \\ Jajah Fachiroh \\ Universitas Gadjah Mada \\ Dewajani Purnomosari \\ Universitas Gadjah Mada \\ Dewi Kartikawati Paramita \\ Universitas Gadjah Mada \\ Yustina Andwi Ari Sumiwi \\ Universitas Gadjah Mada \\ Dian Eurike Septyaningtrias \\ Universitas Gadjah Mada}

Rina Susilowati ( $\nabla$ rina_susilowati@ugm.ac.id)

\section{Research Article}

Keywords: Online course, grading, predictor factor, cell biology, student achievement

Posted Date: February 19th, 2021

DOl: https://doi.org/10.21203/rs.3.rs-209488/v1

License: (9) (1) This work is licensed under a Creative Commons Attribution 4.0 International License. Read Full License 


\section{Abstract \\ Background}

Lack of direct contact with the students in online courses can result in lower lecturer's awareness of their engagement and progress. Examination scores generally have the highest proportion in determining students' grades. Predicting examination scores from the earliest point of the course may be useful in designing timely and appropriate interventions.

\section{Aim}

To analyze the predictors of midterm and final examination scores in an online cell biology course of health nutrition in the undergraduate program at the Faculty of Medicine, Public Health and Nursing Universitas Gadjah Mada, Yogyakarta Indonesia.

\section{Methods}

The learning materials including texts, PowerPoints, videos and miniquizzes were uploaded in a course management system before conducting online meetings. In total, 10 different topics were delivered. Pretest and posttest, both not used for grading, were given at the first and last online meeting. Components of the final score were classroom assessments, group assignments, midterm and final examinations. Students $(n=154)$ were divided into three groups based on their final examination scores, i.e., low, middle and high score. Each component of the final score was reported as mean \pm standard deviation and the mean difference between groups was analyzed. Linear regression analysis was performed to reveal the main predictors of the midterm and final exam scores. Two-step cluster analysis determined by the earliest-obtained scores was performed to identify low achieving students.

\section{Results}

Students with higher final examination scores had significantly higher scores for pretest, posttest, pre and postmidterm class assessments, midterm exam and group assignments $(p<0.05)$. Premidterm class assessment was the main predictor of the midterm exam score. Midterm exam score was the strongest predictor of final exam score and clustering using midterm-premidterm scores identified $75 \%$ of low achieving students. To assist students with low and middle achievement, several modifications were considered such as providing longer and multiple access to the learning and formative test materials, facilitating a communication platform with fellow students and sending personal encouraging messages.

\section{Conclusion}

Scores obtained in various activities during the course potentially predict student grades. The activities should be optimized to improve students' achievement especially for the less privileged students. 


\section{Introduction}

The Cell Biology course is one of the basic courses for the health nutrition undergraduate program at the Faculty of Medicine, Public Health and Nursing Universitas Gadjah Mada in Yogyakarta, Indonesia. Like every other class, the students are separated into high, middle and low achieving students at the end of the course. The high achieving students usually have better prior knowledge [1], are faster adapted learners and have more privileges in accessing learning facilities [2]. Giving special attention to less advantaged students can potentially boost their learning progress into a better achievement $[3,4]$. However, managing students with different backgrounds, motivation, and learning abilities is very challenging.

Online courses require pre-class, in-class and after-class activities to promote a more active learning environment that can increase student engagement [5]. However, potentially low achieving students are more difficult to detect in an online course, since the lecturers and students are not within the same room and the time for online face to face contact is limited and often shorter than in-class meetings. Therefore, early detection of low achieving students will provide more opportunity to overcome some of their challenges and problems in achievement $[6,7]$. This study aimed to analyze the predictors of midterm and final examination scores in an online cell biology course of health nutrition in the undergraduate program at the Faculty of Medicine, Public Health and Nursing Universitas Gadjah Mada, in Yogyakarta, Indonesia.

\section{Methods}

\section{Course description}

The course is offered online and conducted by a teaching team. The online meetings are scheduled once a week for 100-minute sessions lasting 13 weeks. At the first meeting, the students receive an explanation of the whole program and are introduced to the lecturers. Course materials such as videos, PowerPoints and texts are uploaded into a course management system, at least 3 days before each scheduled meeting. An online mini quiz of each weekly topic is provided and the students should submit their answers before each meeting. The scores of the mini quizzes do not contribute to the students' final grade for the course.

The time allocation during online meetings is mostly used for discussing students' answers from the mini quizzes as well as for a question and answer session before the lecturers presented additional explanation. At the end of the meeting, a classroom assessment is given for 15 minutes. Alternatively, after-meeting assignments are given for several topics. For the rest of the text and for analysis purposes, the term classroom assessment will be used for both activities. The scores of the classroom assessments contribute to the students' final grade for the course.

Another component of the final score is the group assignment of 2-3 students. Each group is assigned a topic and must create a poster, crossword puzzle, or video related to their topic of choice. These are uploaded into a social media platform. Each group receives comments and questions from other students and the lecturers. Scientific accuracy and creativity in their presentation and discussion are scored by the lecturers. 
Table 1

The program, number of activities and the percentage of the scores for grading

\begin{tabular}{|c|c|c|c|c|c|c|c|c|c|}
\hline Session / topic & Pretest & $\begin{array}{l}\text { Pre } \\
\text { midterm } \\
\text { mini } \\
\text { quizzes }\end{array}$ & $\begin{array}{l}\text { Pre- } \\
\text { midterm } \\
\text { class } \\
\text { assess } \\
\text { ment }\end{array}$ & $\begin{array}{l}\text { Mid } \\
\text { term } \\
\text { exam }\end{array}$ & $\begin{array}{l}\text { Post } \\
\text { midterm } \\
\text { mini } \\
\text { quizzes }\end{array}$ & $\begin{array}{l}\text { Post- } \\
\text { midterm } \\
\text { class } \\
\text { assess } \\
\text { ment }\end{array}$ & $\begin{array}{l}\text { Group } \\
\text { assign } \\
\text { ment }\end{array}$ & $\begin{array}{l}\text { Post- } \\
\text { test }\end{array}$ & $\begin{array}{l}\text { Final } \\
\text { exam }\end{array}$ \\
\hline & $0 \%$ & $0 \%$ & $9 \%$ & $25 \%$ & $0 \%$ & $11 \%$ & $15 \%$ & $0 \%$ & $40 \%$ \\
\hline Introduction & 1 & & & & & & & & \\
\hline $\begin{array}{l}\text { Cell and } \\
\text { organelles }\end{array}$ & & 1 & 1 & & & & & & \\
\hline Cell membrane & & 1 & 1 & & & & & & \\
\hline $\begin{array}{l}\text { Cellular } \\
\text { energetic }\end{array}$ & & 1 & 1 & & & & & & \\
\hline $\begin{array}{l}\text { Gene } \\
\text { expression }\end{array}$ & & 1 & 1 & & & & & & \\
\hline $\begin{array}{l}\text { Review \& } \\
\text { discussion }\end{array}$ & & & 1 & & & & & & \\
\hline $\begin{array}{l}\text { Examination } \\
\text { week }\end{array}$ & & & & 1 & & & & & \\
\hline $\begin{array}{l}\text { Intercellular } \\
\text { communication }\end{array}$ & & & & & 1 & 1 & & & \\
\hline $\begin{array}{l}\text { Cytoskeleton } \\
\text { and } \\
\text { extracellular } \\
\text { matrix }\end{array}$ & & & & & 1 & 1 & & & \\
\hline $\begin{array}{l}\text { Cell cycle and } \\
\text { cell division }\end{array}$ & & & & & 1 & 1 & & & \\
\hline $\begin{array}{l}\text { Meiosis and } \\
\text { pattern of } \\
\text { inheritance }\end{array}$ & & & & & 1 & 1 & & & \\
\hline $\begin{array}{l}\text { Fertilization } \\
\text { and intrauterine } \\
\text { development }\end{array}$ & & & & & 1 & 1 & & & \\
\hline $\begin{array}{l}\text { Cell damage } \\
\text { and cell death }\end{array}$ & & & & & 1 & 1 & & & \\
\hline $\begin{array}{l}\text { Final } \\
\text { presentation } \\
\text { and discussion } \\
\text { of group } \\
\text { assigment }\end{array}$ & & & & & & & 1 & 1 & \\
\hline $\begin{array}{l}\text { Examination } \\
\text { week }\end{array}$ & & & & & & & & & 1 \\
\hline $\begin{array}{l}\text { Number of } \\
\text { activities }\end{array}$ & 1 & 4 & 5 & 1 & 6 & 6 & 1 & 1 & 1 \\
\hline
\end{tabular}




\begin{tabular}{|c|c|c|c|c|c|c|c|c|c|}
\hline Session / topic & Pretest & $\begin{array}{l}\text { Pre } \\
\text { midterm } \\
\text { mini } \\
\text { quizzes }\end{array}$ & $\begin{array}{l}\text { Pre- } \\
\text { midterm } \\
\text { class } \\
\text { assess } \\
\text { ment }\end{array}$ & $\begin{array}{l}\text { Mid } \\
\text { term } \\
\text { exam }\end{array}$ & $\begin{array}{l}\text { Post } \\
\text { midterm } \\
\text { mini } \\
\text { quizzes }\end{array}$ & $\begin{array}{l}\text { Post- } \\
\text { midterm } \\
\text { class } \\
\text { assess } \\
\text { ment }\end{array}$ & $\begin{array}{l}\text { Group } \\
\text { assign } \\
\text { ment }\end{array}$ & $\begin{array}{l}\text { Post- } \\
\text { test }\end{array}$ & $\begin{array}{l}\text { Final } \\
\text { exam }\end{array}$ \\
\hline
\end{tabular}

Online meetings were scheduled in each session (13 times in total), except in examination week.

The midterm exam with 40 single best answer multiple choice questions (MCQs) and the final exam (60 MCQs) are conducted on designated exam weeks. The students are required to turn on the camera in their second device to enable the lecturer to observe their activity during the midterm and final examinations. One lecturer and one assistant supervise between 21-33 students. The questions for the final examination test only cover topics delivered after the midterm examination. The percentage proportions of the final score are as follows: $20 \%$ from classroom assessments ( $9 \%$ and $11 \%$ for pre- and post-midterm, respectively; depending on the number of topics), $15 \%$ from group assignments, $25 \%$ from the midterm examination, and $40 \%$ from the final examination (Table 1). Scores range from 0-100.

To analyze the students' overall progress, a pretest and posttest that are not included in calculating the final grading are given for 30 minutes at the first and the last online meeting. The MCQs in the pretest are exactly the same as the questions used for posttest, but the same set of questions is not used in the midterm and final examinations.

\section{Statistical analysis}

The final examination score has the highest proportion of the final score and was obtained at the very end of the course. Therefore, the final examination scores were divided into three equal ranges and used to divide the students into tertiles, i.e., low, middle and high achieving students. Other scores were presented as mean \pm standard deviation and mean differences between final examination groups were analyzed with Anova or Kruskal-Wallis tests. Linear regression analysis was performed with the midterm or final examination scores as the dependent variable, by using other performance scores added to the model in stepwise fashion.

The results of the linear regression analysis were used to analyze scores from several activities that contribute to the examination scores. To reveal whether scores obtained earlier in the course may be used to identify low achieving students, Two-step cluster analysis was performed using the premidterm scores, i.e., pretest, premidterm miniquizzes and premidterm class assignments as inputs. Midterm examination scores were added for the second analysis. Correlations of the clusters to final examination score were analyzed with chi-squared tests. The statistical analysis was performed using SPSS ver. 23, with $p<0.05$ considered as statistically significant.

\section{Results}

A total of 154 students enrolled in the course and were included in the analysis. Almost all of the students were female (146). The students consisted of 108 new enrollments and 46 retakers. Even though the tests were not used for grading, most of the students took the pretest and posttest. Only 15 students (9.7\%) did not take the pretest or posttest or both. Most of the posttest scores were higher than the pretest scores, with only 11 students who got lower posttest scores. The average of posttest scores for the whole class $(75.81 \pm 26.8)$ was significantly higher than the pretest score $(31.56 \pm 8.40 ; p<0.001)$. 
Table 2

Mean difference of scores obtained throughout the course in low, middle and high achieving groups.

\begin{tabular}{|c|c|c|c|c|}
\hline & Low $(n=54)$ & $\begin{array}{l}\text { Middle }(n= \\
52)\end{array}$ & High $(n=48)$ & $p$ value \\
\hline Score of Pretest $(n=48,48,46)^{a}$ & $29.24 \pm 8.32$ & $32.71 \pm 7.74$ & $33.12 \pm 8.60$ & $0.044^{c}$ \\
\hline Score of Posttest $(n=50,50,45)^{a}$ & $\begin{array}{l}67.60 \pm \\
29.78\end{array}$ & $72.20 \pm 25.32$ & $\begin{array}{l}85.04 \pm \\
22.37\end{array}$ & $\begin{array}{l}< \\
0.001^{d}\end{array}$ \\
\hline Posttest - pretest $(n=47,48,44)^{a}$ & $\begin{array}{l}40.14 \pm \\
29.13\end{array}$ & $41.46 \pm 26.98$ & $\begin{array}{l}52.73 \pm \\
21.82\end{array}$ & $0.073^{\mathrm{d}}$ \\
\hline $\begin{array}{l}\text { Number of premidterm miniquizzes taken (max } \\
\text { 4) }\end{array}$ & $3.69 \pm 0.82$ & $3.88 \pm 0.47$ & $4.00 \pm 0.00$ & $0.010^{d}$ \\
\hline $\begin{array}{l}\text { Number of postmidterm miniquizzes taken (max } \\
6 \text { ) }\end{array}$ & $5.17 \pm 1.49$ & $5.63 \pm 0.66$ & $5.81 \pm 0.67$ & $0.011^{d}$ \\
\hline$\%$ student took all mini quizzes & 64.81 & 66.67 & 79.63 & $0.001^{\mathrm{e}}$ \\
\hline Score of pre midterm miniquizzes ${ }^{f}$ & $\begin{array}{l}50.68 \pm \\
18.16\end{array}$ & $53.46 \pm 15.62$ & $\begin{array}{l}59.15 \pm \\
14.78\end{array}$ & $0.032^{c}$ \\
\hline Score of postmidterm miniquizzes ${ }^{g}$ & $\begin{array}{l}53.28 \pm \\
20.01\end{array}$ & $63.60 \pm 13.84$ & $\begin{array}{l}69.92 \pm \\
16.38\end{array}$ & $<0.001^{d}$ \\
\hline Score of midterm exam ${ }^{b}$ & $\begin{array}{l}54.49 \pm \\
12.23\end{array}$ & $65.96 \pm 9.87$ & $74.32 \pm 9.92$ & $\begin{array}{l}<.001^{d} \\
0\end{array}$ \\
\hline Score of premidterm-class assessment ${ }^{\mathrm{b}, \mathrm{h}}$ & $\begin{array}{l}61.46 \pm \\
11.57\end{array}$ & $66.69 \pm 9.13$ & $69.81 \pm 7.84$ & $\begin{array}{l}< \\
0.001^{d}\end{array}$ \\
\hline Score of postmidterm-class assessment ${ }^{\mathrm{b}, \mathrm{i}}$ & $\begin{array}{l}51.85 \pm \\
14.76\end{array}$ & $62.04 \pm 9.22$ & $\begin{array}{l}67.93 \pm \\
13.58\end{array}$ & $\begin{array}{l}< \\
0.001^{d}\end{array}$ \\
\hline Score of group assignment ${ }^{b}$ & $75.71 \pm 4.42$ & $77.87 \pm 5.40$ & $79.18 \pm 4.68$ & $0.002^{c}$ \\
\hline \multicolumn{5}{|c|}{$\begin{array}{l}\text { Means of final score were } 39.41 \pm 6.66,54.39 \pm 3.85,71.39 \pm 6.64 \text { in low, middle and high achieving group, } \\
\text { respectively. }{ }^{a} \mathrm{n} \text { for low, middle and high achieving group. }{ }^{\mathrm{b}} \text { score used for grading }{ }^{\mathrm{c}} \text { Anova }{ }^{\mathrm{d}} \text { Kruskal-Wallis } \\
\text { Chi-squared }{ }^{\mathrm{f}} \text { no difference between group for each quizzes }{ }^{9} \text { high achieving students had higher score in } 4 \text { out } \\
\text { of } 6 \text { quizzes }{ }^{\mathrm{h}} \text { high achieving students scores were higher in } 2 \text { out of } 6 \text { assessments 'high achieving students } \\
\text { had higher scores in all } 6 \text { assessments; max, maximum. }\end{array}$} \\
\hline
\end{tabular}

Based on the final examination scores, the students were divided into three groups, i.e. low (mean final exam score $39.41 \pm 6.66)$, middle $(54.39 \pm 3.85)$ and high $(71.39 \pm 6.64)$ achieving groups. The means of the other scores obtained during the program are presented in Table 2. High achieving students got the highest scores in all of the assessments, including the tests that were not used as grading components, i.e., pretest, posttest and miniquizzes. The mean increase in posttest scores from the pretest was higher in the high achieving group (52.73 $\pm 21.83)$ compared to the other two groups, i.e., middle achieving group $(41.46 \pm 26.98)$ and low achieving group $(40.14 \pm 29.13)$, but the difference was not significant statistically $(p=0.073)$.

The miniquizzes were provided several days before the lectures and the scores were not used for grading. Results showed that the number of quizzes taken and their scores were lower in the low achieving group (Table 2). More 
students took all miniquizzes in the high achieving group $(79.63 \%)$ than the percentage in the middle $(66.67 \%)$ and lower (64.81\%) achieving students.

Table 3

Predictors for midterm exam score

\begin{tabular}{|lllll|}
\hline & Adjusted R square & $\mathbf{B}$ & $95 \% \mathbf{C l}$ & p value \\
\hline univariate & & & & \\
\hline pretest & 0.008 & 0.202 & $-0.067-0.472$ & 0.140 \\
\hline premidterm miniquizzes & 0.026 & 4.278 & $0.555-8.002$ & 0.025 \\
\hline premidterm class assessment & 0.158 & 0.531 & $0.339-0.724$ & $<0.001$ \\
\hline multivariate & & & & \\
\hline Model 1 & 0.153 & & & $<0.001$ \\
\hline premidterm miniquizzes & & 0.158 & $-3.696-4.013$ & 0.935 \\
\hline premidterm class assessment & & 0.527 & $0.313-0.742$ & $<0.001$ \\
\hline Model 2 & 0.133 & & & $<0.001$ \\
\hline pretest & & 0.16 & $-0.095-0.415$ & 0.216 \\
\hline premidterm miniquizzes & & 2.047 & $-3.116-7.210$ & 0.434 \\
\hline premidterm class assessment & & 0.497 & $0.266-0.727$ & $<0.001$ \\
\hline
\end{tabular}

Table 4

Univariate analysis for predictors of the final exam score

\begin{tabular}{|llll|}
\hline & beta & $95 \% \mathrm{Cl}$ & $\boldsymbol{p}$ value \\
\hline Univariate & 0.702 & $0.575-0.830$ & $<0.001$ \\
Midterm & & & \\
\hline Postmidterm class assessment & 0.476 & $0.336-0.616$ & $<0.001$ \\
\hline Premidterm class assessment & 0.425 & $0.257-0.593$ & $<0.001$ \\
\hline Postmidterm miniquizzes & 0.347 & $0.234-0.459$ & $<0.001$ \\
\hline Premidterm miniquizzes & 0.325 & $0.101-0.549$ & 0.005 \\
\hline Group assignment & 0.719 & $0.279-1.159$ & 0.002 \\
\hline Posttest & 0.158 & $0.075-0.241$ & $<0.001$ \\
\hline Pretest & 0.019 & $0.003-0.035$ & 0.023 \\
\hline Post-pretest gap & 0.121 & $0.007-0.034$ & 0.007 \\
\hline
\end{tabular}

Table 5. Stepwise multivariate analysis of predictors for final examination 


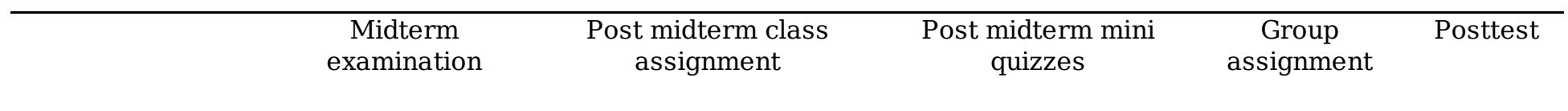

\begin{tabular}{lccc}
\hline $\begin{array}{l}\text { Model 1 } \\
\text { Adjusted } \\
\mathrm{R}^{2}\end{array}$ & & & \\
$\mathrm{~B}$ & 0.491 & & \\
\hline $95 \% \mathrm{CI}$ & & 0.596 & 0.265 \\
\hline$p$ value & $<0.001$ & $<0.001$ & $0.141-0.387$ \\
& & & $<0.001$ \\
\hline
\end{tabular}

Model 2

Adjusted

$\begin{array}{ll}\mathrm{R}^{2} & 0.507\end{array}$

$\mathrm{B}$

95\%CI

0.582

0.226

1.922

$p$ value $\quad<0.001$

0.453-0.711

0.102-0.351

0.335-3.508

$<0.001$

0.018

Model 3

Adjusted

$\mathrm{R}^{2}$

0.529

B

$<0.001$

95\%CI

0.523

0.209

0.151

0.332

$p$ value

$<0.001$

0.391-0.652

0.087-0.330

0.056-0.245

0.014-0.650

$<0.001$

0.001

0.001

0.041

Model 4

Adjusted

$\mathrm{R}^{2}$

0.542

B

0.541

0.197

0.128

0.382

0.006

95\%CI

0.409-0.674

0.074-0.320

0.022-0.235

0.055-0.708

$-0.062-$

$p$ value

$<0.001$

$<0.001$

0.002

0.019

0.022

0.865

The univariate and multivariate analyses of predictors of midterm examination scores are presented in Table 3. Results showed that the pretest scores did not significantly predict the midterm exam scores (B $0.202 ; 95 \% \mathrm{Cl}$ : $-0.067-0.472 ; p=0.140$ ). As an early progress indicator, pre-midterm class assignment was a significant predictor of the midterm exam score (B 0.450; 95\%Cl: 0.295-0.605; $p=<0.001)$.

Results from the univariate analysis of the predictors of the final exam score are shown in Table 4. All scores were positively correlated with the final examination score $(p<0.05)$. The midterm exam score was the main single predictor of the final exam score in the multivariate analysis, contributing significantly to the four models shown in Table 5. Postmidterm class assessment added in model 1 (adjusted R squared 0.491, $p<0.001$ ), postmidterm miniquizzes added in model 2 and group assignment added in model 3 contributed to the final exam score prediction. Midterm exam score and all scores obtained after the midterm (postmidterm class assignment; group assignment, postmidterm miniquizzes and posttest) contributed in the best model (model 4 , adjusted $\mathrm{R}$ squared $0.542, p<0.001$ ). Although not used in the final grading, the contribution of postmidterm miniquizzes was significant in the prediction model.

Two-step cluster analysis using premidterm scores, i.e. pretest, premidterm miniquizzes and premidterm class assessments as inputs, revealed four clusters with fair cluster quality and ratio of sizes of 2.14. Only 142 students were included in this analysis because 12 students had incomplete data. The number of students in each cluster from low to high achievers were $38,45,21$, and 38 , respectively. Adding midterm examination scores 
determined 2 clusters with a better ratio of sizes of 1.15 (76 students in the high achieving cluster and 66 in the low achieving cluster). Figure 1 shows the correlations of final examination achievement (low, middle and high) with the four clusters of premidterm scores (Fig. 1A; chi-squared 21.64, df 6, $p$ value 0.001) and midtermpremidterm scores (Fig. 1B; chi-squared 29.23, df 2, $p$ value < 0.001). Based on their final examination scores, only $25 \%$ of students in the low achieving group were identified using premidterm score clustering. In comparison, $75 \%$ of the low achieving students were identified using midterm-premidterm clustering.

\section{Discussion}

In this study, the overall progress of students' knowledge throughout the course is reflected in the improved pretest-posttest scores. However, the single group pretest posttest design has several limitations as reviewed recently [8]. Although the pretest score was not a significant predictor of the midterm test score, the pretest is the earliest test taken by the newly enrolled students. The questions in the pretest encompass all of the pre and post midterm topics, but the correlation of the pretest score with the midterm and final exam score is low. Entrance exam scores are additional pre-course data that have been shown to be a strong predictor of students' achievement [9]. However, not every course coordinator has access to the entrance scores and they may not be equally related to student achievement in various specific courses. Providing the pretest with similar types of questions used in the later examinations also can give students an overview to the subject material and provide some details of the knowledge that should be gained and will be tested during the course.

Two-step cluster analysis is useful for predicting student achievement [10]. Detection of low achieving students as early as possible is important but can be challenging. Using premidterm scores, the students are divided into four clusters and the low achievers are distributed almost equally to the three groups based on final examination score. Therefore, the four clusters are not useful for prediction and subsequent intervention. Adding the midterm examination score to the premidterm scores revealed two clusters that predict the final examination result more accurately. At the time of the midterm, $34 \%$ of the overall scores were already obtained but the other $66 \%$ could still be improved after the midterm.

Ideally, the identification of low achieving students should be followed by an appropriate intervention [11]. By nature, the middle achieving students may have more probability to improve by proper interventions [12]. The challenge for the lecturers is in providing timely interventions that are equally encouraging for all students. The use of information technology has been reported to be advantageous and can enrich students' understanding [13]. In online courses, the use of videos is an interesting method for content delivery and may improve students' understanding [14]. However, low achieving students may need more direct face to face explanations from the lecturer [15].

In this course, the study material accompanied by miniquizzes are provided several days before the online meeting. Providing the material earlier may give low achieving students more opportunity to self-adjust to the schedule of their learning activities [16]. Additionally, improving the study material into a better guided learning resource may improve basic science learning for under privileged students as reported by a previous review [17]. Data on the student access to the videos and provided materials can be obtained from the learning management system. However, many students prefer to download the video and learning material making it difficult to track the frequency that the materials are used. Although not part of the grading components, the strong contribution of miniquizzes in determining examination scores may reflect the individual students' resources such as time and 
speed to access the Internet and their level of motivation. The tasks or questions in the miniquizzes are varied and the students' answers are discussed during the online meetings to increase their motivation. Allowing multiple access to the learning materials and providing the miniquizzes earlier can provide more time and opportunity for low achieving students to take more quizzes and benefit more from the learning process.

The project assignment in small groups also provides a significant contribution to the learning process. In this course, the students create a video, poster or crossword puzzle with an assigned topic related to the lectures. Providing a platform for communicating with other students is crucial in distant learning. Other possible assignments as peer-learning activities may be considered [18].

Class assessment for some topics can be replaced by after class assignments, since they give more time for low achieving students to learn. In this way, low achieving students will have opportunity to communicate with other students. Moreover, using a variety of assignment types is reported to increase student enthusiasm and make the learning process more enriching and exciting [19]. The feedback from our students confirmed the efficacy of this approach. Class assessment contributes significantly to student achievement in the examinations, probably by acting as a stimulus for more active learning through increasing the students' motivation and retention [20]. However, class assessments may add some stress for the low achieving students that could be counterproductive.

As the online course begin at the beginning of the unexpected global pandemi, many students are experiencing online learning for the first time. Being unfamiliar with online learning may add to students anxiety. Student anxiety especially in learning basic bioscience is suggested to be problematic by a previous study [21]. Anxiety may induce maladaptive coping mechanisms such as avoidance and isolation [22] that are more difficult to detect in an online course.

Exposure to similar types of questions may give some advantage to the students because the learning strategy needs to be adjusted to the type of questions provided in the examination. Limited familiarity with the MCQs used in the midterm and final examinations could become an obstacle for middle and low achieving students. Providing a bank of questions accessible to the student throughout the course as part of the learning process may give the students more opportunity to practice in taking examinations [23]. However, the method requires more effort from the lecturers in authoring the MCQs. Other than the pretest and posttest, students usually have access to a similar set of MCQs used in the course examinations of the previous batch from senior students. The lecturers are aware of this phenomenon and need to create new set of questions for every batch. Whether the first year students during online courses in the pandemic era obtain course information from their seniors is an interesting subject to be investigated.

Cheating is another issue to consider in every assessment [24], especially in online courses. We supervise the midterm and final examinations, but not the class assessments. Judging from their answers and scores, we trust our students' honesty is upright based on professionalism and an 'honor system'. Encouraging student integrity is also an important part of an educator's task and we always deliver this message to the students. Nevertheless, further study needs to be done on this subject, particularly related to issues concerning plagiarism.

One limitation of this study is the scores of the students who are retakers of the course were not separately presented. These students have the advantage of being exposed to the course content previously. However, apart from the students with low grades who are obliged to retake the course, some of the retakers are middle achieving 
students that want to improve their grade. Another limitation is the lack of data concerning the learning strategy based on student motivation, concentration, learning resources, anxiety, and environment at home. The learning strategy is another factor that can influence students' achievement [12]. Recent research showed online learning behavior [9] and social networking in online collaborative learning [25] also contribute to student performance. Because motivation and engagement differ majorly between the high achieving students and the low achieving students [26], increasing their motivation and engagement can be a significant factor to improve outcomes. Also, this course is delivered in the first semester, when the new students have to adapt to the higher education environment which may become an additional burden for some of them [27]. Although in online courses, homesickness may not be a problem, time management and socializing with lecturers and other students may become more challenging. Obtaining those data is another challenge in research concerning online education. Due to the specific context of this course offering in the medical professions program, the findings in this study may not be extrapolated and generalized to other programs.

One way to increase student motivation is by giving assignments early in the course about the relevancy and the benefits of the course topics to the student daily experiences [3]. This kind of intervention conveys the significance of the course topic and, thus, can stimulate greater interest in particular topics. Gamification of inclass activities is also valuable in encouraging student motivation [28]. However, the effect of gamification on learning depends on the design and difficulty level of the game or quiz [29]. Providing students information about their current grade in the course can also be an effective tool to increase motivation [30, 31]. Table 6 lists some possible interventions that may benefit low and middle achieving students. In general, the modifications of the program can provide more time for low and middle achieving students to learn the study material and the opportunity to challenge themselves by taking a quiz or test in multiple attempts. The availability of supplemental resources should be considered in selecting appropriate interventions. 
Table 6

Interventions that may benefit low and middle achieving students

\begin{tabular}{|c|c|c|}
\hline Activities & in this course & possible modification / intervention \\
\hline $\begin{array}{l}\text { Availability of } \\
\text { learning material } \\
\text { (text, video) }\end{array}$ & $\begin{array}{l}2-4 \text { days before the } \\
\text { schedule }\end{array}$ & $\begin{array}{l}\text { at the beginning of the course, more examples on } \\
\text { daily application }\end{array}$ \\
\hline Mini-quizzes & $\begin{array}{l}\text { single trial, days before } \\
\text { online meeting }\end{array}$ & $\begin{array}{l}\text { enable multiple trials, available at the beginning of } \\
\text { the course }\end{array}$ \\
\hline Online meeting & emphasizing on question & additional explanation on selected topic \\
\hline Class assessments & $\begin{array}{l}\text { single trial, during the } \\
\text { online meeting or after } \\
\text { class assignment }\end{array}$ & $\begin{array}{l}\text { several trials with mark points deducted in second } \\
\text { trial and so on while maintaining the variability of the } \\
\text { task }\end{array}$ \\
\hline Group assignment & $\begin{array}{l}\text { after midterm, feedback } \\
\text { delivery still can be } \\
\text { improved }\end{array}$ & $\begin{array}{l}\text { early group formation starting after second meeting, } \\
\text { regrouping may be considered after midterm, high } \\
\text { quality feedback }\end{array}$ \\
\hline Points earning & $\begin{array}{l}\text { not all scores revealed } \\
\text { immediately to the } \\
\text { students }\end{array}$ & $\begin{array}{l}\text { students may monitor their own points at any stage } \\
\text { of the course }\end{array}$ \\
\hline $\begin{array}{l}\text { Familiarity with the } \\
\text { questions used in } \\
\text { examination }\end{array}$ & $\begin{array}{l}\text { pretest and posttest, one } \\
\text { trial each }\end{array}$ & $\begin{array}{l}\text { additional questions for practice, with multiple trial } \\
\text { enabled setting }\end{array}$ \\
\hline $\begin{array}{l}\text { Special attention to } \\
\text { the low achieving } \\
\text { students }\end{array}$ & $\begin{array}{l}\text { minimal, during online } \\
\text { meeting or via social } \\
\text { media }\end{array}$ & scheduled some encouraging personal messages \\
\hline
\end{tabular}

In conclusion, we analyzed and identified several predictors of the midterm and final examination scores in an online Cell Biology course for our undergraduate health nutrition program. We discussed several possibilities of using the results of this analysis for redesigning and improving our online courses, especially to assist low and middle achieving students.

\section{Declarations}

- Ethics approval and consent to participate

The data for this study was retrieved retrospectively from the course database and the identity of the students remained anonymous. Individual student consent was waived by the approval from the Medical and Health Research Ethic Committee of the Faculty of Medicine, Public Health and Nursing, Universitas Gadjah Mada (Ref: KE/0066/01/2021). All methods were carried out in accordance with guidelines and regulations of Universitas Gadjah Mada.

- Consent for publication

Not applicable

- Availability of data and materials 
The datasets used and/or analysed during the current study are available from the corresponding author on reasonable request.

- Competing interests

The authors declare that they have no competing interest

- Funding

This work did not receive any specific grant from funding agencies in the public, commercial, or not-for-profit sectors.

- Authors' contributions

Conception and design- R.S.; Acquisition of data- R.S., J.F. D.P., D.K.P, Y.A.A.S, D.E.S.; Analysis and interpretation of data R.S.; Drafting manuscript- R.S. ; Revising manuscript and approved the submitted version- R.S., J.F. D.P., D.K.P, Y.A.A.S, D.E.S.

- Acknowledgements

The authors want to thank Mr. Muryadi and the staff at Klinik Bahasa, Office of Research and Publication, Faculty of Medicine, Public Health and Nursing, Universitas Gadjah Mada who kindly provided technical assistance and proofreading assistance, respectively.

\section{References}

1. Thompson RA, Zamboanga BL. Prior knowledge and its relevance to student achievement in introduction to psychology. Teach Psychol. 2003;3(2):96-101.

2. Chiu MM, Khoo L. Effects of resources, inequality, and privilege bias on achievement: Country, school, and student level analyses. Am Educ Res J. 2005;42(4):575-603.

3. Harackiewicz JM, Canning EA, Tibbetts Y, Priniski SJ, Hyde JS. Closing achievement gaps with a utility-value intervention: disentangling race and social class. J Pers Soc Psychol. 2016;111:745-65.

4. Hulleman CS, Kosovich JJ, Barron KE, Daniel DB. Making connections: replicating and extending the utility value intervention in the classroom. J Educ Psychol. 2017;109:387-404.

5. Reinke NB. Promoting student engagement and academic achievement in first-year anatomy and physiology courses. Adv Physiol Educ. 2019;43(4):443-50.

6. Al-Shabandar R, Hussain AJ, Liatsis P, Keight R. Detecting at-risk students with early interventions using machine learning techniques. IEEE Access. 2019;7:149464-78.

7. Hung J-L, Wang MC, Wang S, Abdelrasoul M, Li Y, He W. Identifying at-risk students for early interventions: a time-series clustering approach. IEEE Trans Emerg Topics Comput. 2015;5:45-55.

8. Spurlock DR Jr. The single-group, pre- and posttest design in nursing education research: it's time to move on. J Nurs Educ. 2018;57(2):69-71.

9. Tellakat M, Boyd RL, Pennebaker JW. How do online learners study? The psychometrics of students' clicking patterns in online courses. PloS One. 2019;14(3):e0213863. 
10. Brown SJ, White S, Power N. Tracking undergraduate student achievement in a first-year physiology course using a cluster analysis approach. Adv Physiol Educ. 2015; 39(4):278-82.

11. Li S, Liao X, Burdick W, Tong K. The effectiveness of flipped classroom in health professions education in China: a systematic review. J Med Educ Curric Dev. 2020;7:2382120520962838.

12. Kritzinger A, Lemmens JC, Potgieter M. Learning strategies for first-year biology: toward moving the "Murky Middle". CBE Life Sci Educ. 2018;17(3):ar42.

13. Kim KJ, Kim G. Development of e-learning in medical education: 10 years' experience of Korean medical schools. Korean J Med Educ. 2019;31(3):205-14.

14. Guze PA. Using technology to meet the challenges of medical education. Trans Am Clin Climatol Assoc. 2015;126:260-70.

15. Schreiber BE, Fukuta J, Gordon F. Live lecture versus video podcast in undergraduate medical education: a randomized controlled trial. BMC Med Educ. 2010;10:68.

16. Persky AM, McLaughlin JE. The flipped classroom: from theory to practice in health professional education. Am J Pharm Educ. 2017;81(6):118.

17. Blumer LS, Beck CW. Laboratory courses with guided-inquiry modules improve scientific reasoning and experimental design skills for the least-prepared undergraduate students. CBE Life Sci Educ. 2019;18(1):ar2.

18. Craft JA, Christensen M, Shaw N, Bakon S. Nursing students collaborating to develop multiple-choice exam revision questions: a student engagement study. Nurse Educ Today. 2017;59:6-11.

19. Bhalli MA, Khan IA, Sattar A. Learning style of medical students and its correlation with preferred teaching methodologies and academic achievement. J Ayub Med Coll Abbottabad. 2015;27(4):837-42.

20. Bakon S, Craft J, Christensen M, Wirihana L. Can active learning principles be applied to the bioscience assessments of nursing students? A review of the literature. Nurse Educ Today. 2016;37:123-27.

21. Craft J, Hudson P, Plenderleith M, Wirihana L, Gordon C. Commencing nursing students' perceptions and anxiety of bioscience. Nurse Educ Today. 2013;33(11):1399-405.

22. Brigati JR, England BJ, Schussler EE. How do undergraduates cope with anxiety resulting from active learning practices in introductory biology? PLoS One. 2020; 15(8):e0236558.

23. Kühbeck F, Berberat PO, Engelhardt S, Sarikas A. Correlation of online assessment parameters with summative exam performance in undergraduate medical education of pharmacology: a prospective cohort study. BMC Med Educ. 2019;19(1):412.

24. Desalegn AA, Berhan A. Cheating on examinations and its predictors among undergraduate students at Hawassa University College of Medicine and Health Science, Hawassa, Ethiopia. BMC Med Educ. 2014;14:89.

25. Saqr M, Fors U, Tedre M. How the study of online collaborative learning can guide teachers and predict students' performance in a medical course. BMC Med Educ. 2018;18(1):24.

26. Yip MCW. Differences in learning and study strategies between high and low achieving university students: a Hong Kong study. Educ Psychol. 2007;5:597-606.

27. Ababu BG, Yigzaw BA, Besene DY, Alemu GW. Prevalence of adjustment problem and its predictors among first-year undergraduate students in Ethiopian university: a cross-sectional institution based study. Psychiatry J. 2018;2018:5919743.

28. Yildirim I. The effects of gamification - based teaching practices on student achievement and students' attitudes toward lessons. Internet High Educ. 2017;33:86-92. 
29. Sailer M, Sailer M. Gamification of in-class activities in flipped classroom lectures. Br J Educ Technol. 2020.

30. Smith BO, White DR, Kuzyk PC, Tierney JE. Improved grade outcomes with an e-mailed "grade nudge". J Econ Educ. 2018;49 (1):1-7.

31. Chen Q, Okedjii TO. Incentive matters!-The benefit of reminding students about their academic standing in introductory economics courses. J Econ Educ. 2014;45:11-24.

\section{Figures}

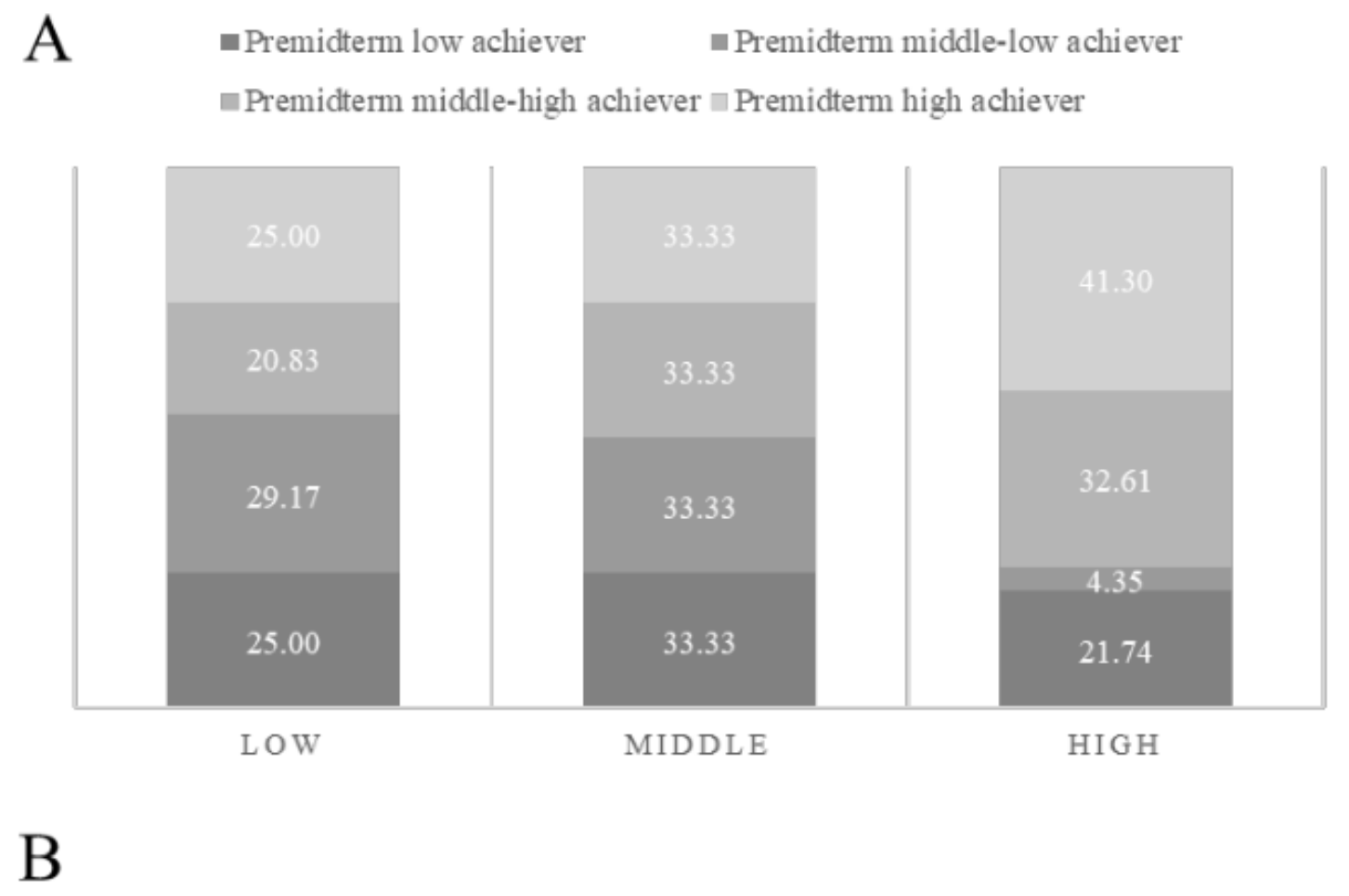

- Midterm-premidterm low achiever $\quad$ Midterm-premidterm high achiever

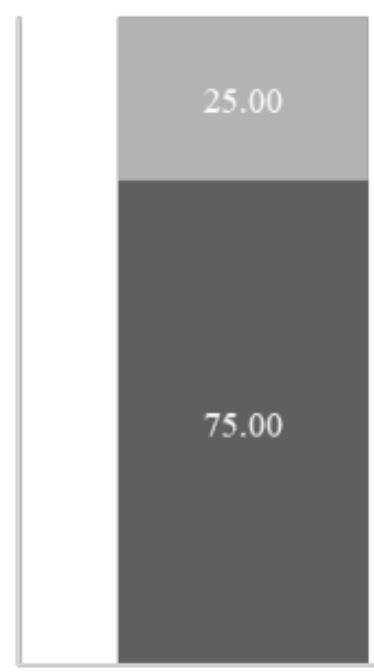

L OW

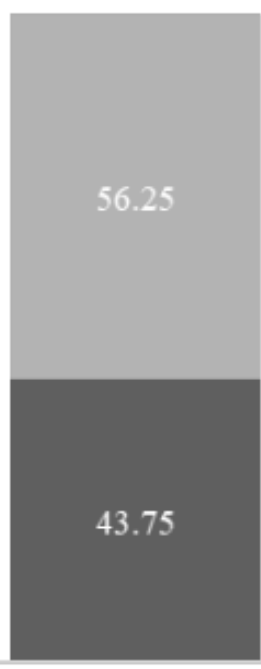

MIDDLE

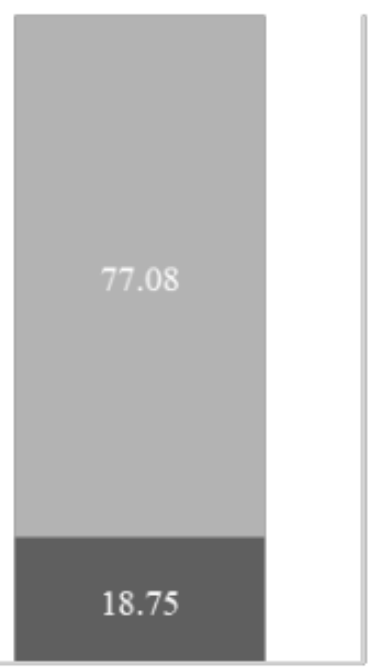

HIGH

\section{Figure 1}


Histogram of Two-step cluster analysis and subsequent chi-squared analysis for 142 students. The numbers shown in the figures were the percentages of the students within the group. A. Correlation of clusters of students based on premidterm scores (4 clusters) with final examination score (3 groups i.e., low, middle, and high). Pearson's chi-squared 21.64, df 6, p value 0.001. B. Correlation of clusters of students based on midtermpremidterm scores ( 2 clusters) with final examination score. Pearson's chi-squared 29.23, df 2 , p value $<0.001$. 